\begin{tabular}{ll}
\hline \hline MINING AND METALLURGY INSTITUTE BOR & ISSN: 2334-8836 (Štampano izdanje) \\
UDK: 622 & ISSN: 2406-1395 (Online) \\
\hline \hline
\end{tabular}

\title{
FORMATION ANALYSIS OF MAGLAJCI - MOŠTANICA OPHIOLYTIC ZONES IN THE NORTH OF KOZARA FOR THE USE OF ROCKS IN CONSTRUCTION
}

\begin{abstract}
Based on the field work and laboratory research, the basic geological characteristics of the ophiolitic melange of northern Kozara are presented, with an emphasis on the Maglajci ophiolitic block. Criteria for separations of formations were established and then applied in the analysis, especially those geologically directly recognizable in the field and outcrops, so one ore formation with two ore subformations was separated in the Maglajci block. In the central zone of block, the basalt outflows and diabase are dominant, while in the south of the block it is an outflow basaltic sequence of the ocean floor with the acidic differences of rhyolites and keratophyres. The second subformation also includes the Moštanica and Vojkova Bloc as a whole. The ore bearing formation is evaluated as a medium to low perspective formation, while parts of the Maglajci block with a massive to brecciated outflow are highly perspective terrain. There are rocks of good physical-mechanical characteristics and they meet the most requesting standards for road building. The results of formation analysis have denied a prior prognosis of ore bearing characteristics of this area, because it was thought that the ophiolitic blocks was built almost exclusively of diabase, and that the fields with those blocks are equally and good perspective for researching the deposits of construction stone.

Keywords: diabase, ophiolitic melange, ore bearing formations, technical-construction stone,
\end{abstract} Kozara

\section{INTRODUCTION}

In the area of northern Kozara the ophiolites are represented by several blocks such as: Trnava, Vojskova, Balj, Mrakodol, Moštanica and Maglajci (Fig. 1). They are an integral part of the ore bearing formation of ophiolites "Ophiolitic melange of the north Kozara", defined according to its dominant member, applying the criterion of paragenetic formation analysis.

Specifically developed parts of the ore formations are the ore subformations. During defining of their specificities follo-wing criteria have been used: level of magma solidification, manner of rock occurrence with different participation, mineralogical and structural - texture characteristics, postmagmatic processes and hydro-thermal alteration, tectonic reshaping, etc.).

When the qualitative - quantitative indicators (basic technical characteristics of rocks and possible application, possibility of exploitation and stone processing, recovery, reserves, etc.) are included to the mentioned geological parameters, possibilities for extraction a wide spectra of subformations and its ranking based on geological and economic significance can be revealed. Criteria and indicators were also used to determine the potentiality of surfaces on which ophiolites appear as rocks used as the technical building stone.

\footnotetext{
${ }^{*}$ Faculty of Mining Prijedor, University in Banja Luka, e-mail: aleksej.milosevic@ @r.unibl.org

*** Mine and TPP Gacko, Industrial zone bb,e-mail:bosko.vukovic@ ritegacko.com
} 


\section{OPHIOLITIC MELANGE OF THE NORTH KOZARA (ORE BEARING FORMATION OPHIOLITES)}

Unlike the southern area, where the ophiolitic melange (diabase-chert formation) is of Jurassic age [1], northern Kozara includes a similar but younger formation defined as the Cretaceous (tectonic) "ophiolitic melange" or "ophiolitic complex" [2]. The formation consists of a sedimentary matrix and blocks of different composition and dimensions. The more prominent magmatic bo- dies, most often in a tectonic contact with the surrounding formations, rarely the contacts are the tectonic olistolytic. These larger bodies account for about $80 \%$ of the surface distribution of formation [3]. In the northern Kozara, the Trnava and Vojkova blocks are highlighted, then the Moštanica block, Mrakodol block and Maglajci block - the subject of this paper (Fig. 1).

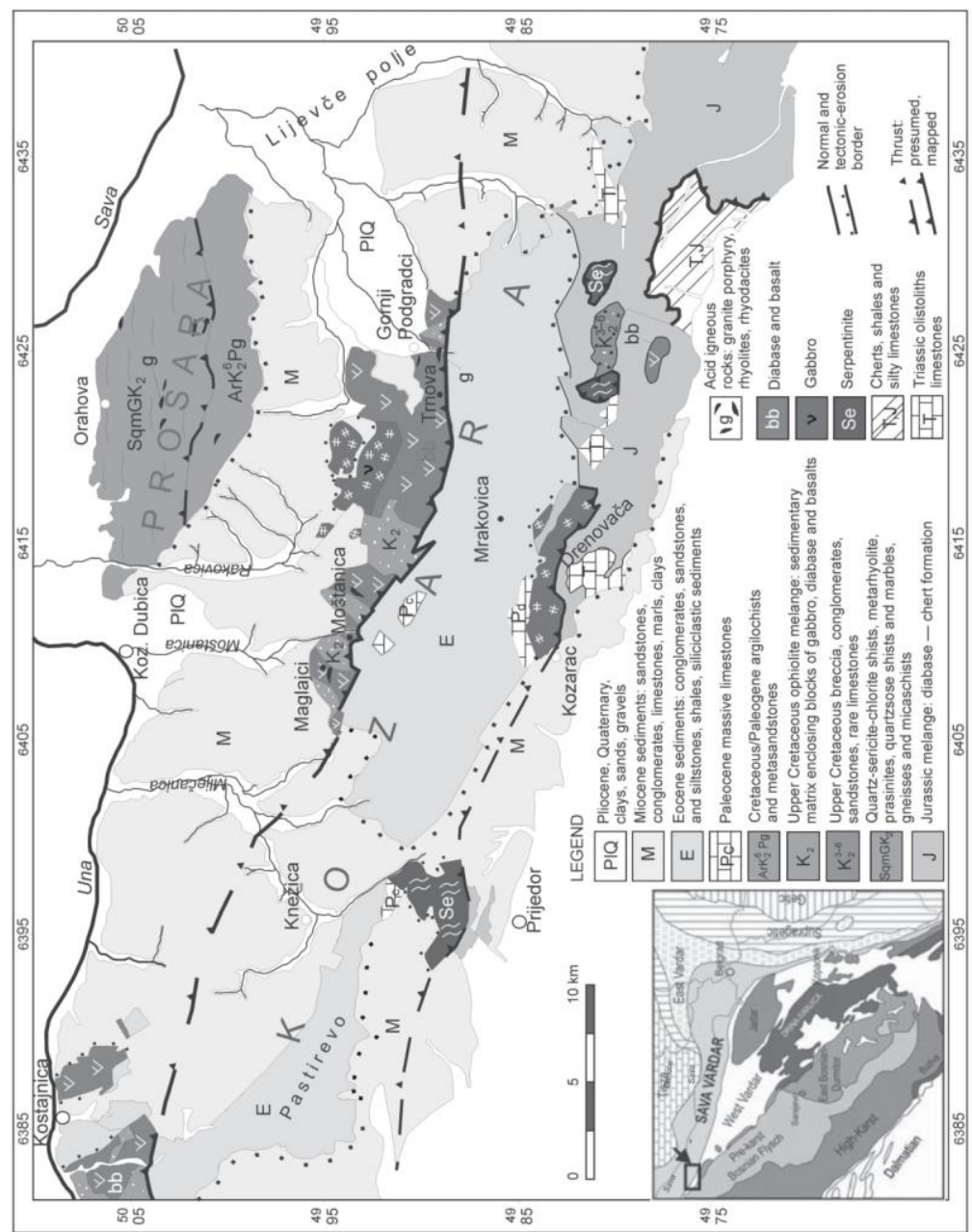

Figure 1 Geological map of the Kozara compiled from sheets the Basic Geological Map of SFR Yugoslavia, changed and supplemented [2, 9] 
Igneous rocks are represented by gabrro, dolerite and diabase dikes and their systems, then basalts, acidic rock dikes and their volcanics. The variety in mineralogical and chemical composition is the result of bimodal intra-oceanic magmatism. Unlike the southern diabase-chert formation, no ultramafits have been identified here.

It is a typical melange of tectonic origin. It is genetically related to the finite, spatially narrowed substantially narrowed parts of the Dinaric part of Tethys, when the process of its closure or collision begins. Based on the results of research on a "chaotic formation" in the western Serbia and Kosmet [4], considering the similarities in the properties of blocks and time of their occurrence with those in northern Kozara, as well as the fact that they belong to the same regional geological unit the genesis of ophiolitic melange is interpreted partly by tectonic, and partly by olistostromic [2].

The Cretaceous age of these formations was assumed by Pamić and Jelaska [5], based on the limestone fragments with calpionella and globotruncans in the melange, and it has been proven by Grubic et al. recent provisions of globotruncans in red limestones "Scaglia Rossa", which were intercalated by pillows - lava $[6,7]$. The mentioned biostratigraphic data are in accordance with the U-Pb ages obtained on zircons from the dolerites of the Vojskova block of 81.6 and $81.4 \mathrm{Ma}$, and also agree well with the K-Ar ages of 79 and $82 \mathrm{Ma}$, obtained from the "whole rock" dolerite from the Trnova diabase complexes [8].

\subsection{Maglajci - Moštanica ophiolitic zone (ophiolitic ore formation)}

In the north of Kozara, the creations diabase - basalt - spilite - keratophyre association rocks were selected that build several ophiolitic blocks, out of which the largest is the Vojskova block (Fig. 3). The rocks occur as fresh, altered and fractured - intensely altered in the form of effusions of magma, pillow-lavas and dikes and alternate on short distances. Basaltic effusions are usually solid with little dikes them break through. Basalts rarely contain phenocrysts of plagioclass surrounded by volcanic glass [9]. The formation matrix consists of alevrolites, sandstones, marls and limestones with all transitions between the last two members.

The Maglajci - Moštanica of ophiolitic zone is built by three ophiolite blocks with different geological and petrographic characteristics. Therefore, the magmatic rocks of this zone are also classified into two ore subformations. The first smaller Basaltic effusions of northern Kozara builds the western parts of the Maglajci block, while the other with the most acidic rock differentiators belong to the other igneous rocks.

\subsubsection{Basaltic effusions of northern Kozara (ophiolitic ore subformation)}

The ophiolitic block Maglajci is located on the northern slopes of Kozara, south of Kozarska Dubica and north of Prijedor. Border of blocks to the south make flysh sediments of the Lower and Middle Eocene represented by conglomerates, sandstones and marls $\left(\mathrm{E}_{1,2}\right)$, and the northern sides are sediments of the terrigenous-carbonate formation of the Lower and Middle Miocene and Sarmatian.

The block is suitable for geological observations on the Maglajci deposit where, on the open profile about $50 \mathrm{~m}$ long and about $20 \mathrm{~m}$ high diabases, the lava effusions occur, subordinate to wire, and in higher parts dominated by the ellipsoidal pillow bodies (Figs. 2 and 5). During magma cooling, the predisposed sputtering directions are created and a plate-like appearance of the basalt mass is formed. At the base of profile, diabase occurs in a form of massive to brechiated basin effusion (Fig. 4). The rock here is not altered, dark gray to greenish-gray in color. The structure, individual fragments and appearance of the rock resemble pillow-lava, however, with more detailed observations, were found to be the 
pseudo pillow-lavas. "Chillded margins" occur in them as a result of the rapid lava cooling. The described rock corresponds to the variety "unaltered diabase", whose thickness on the open profile of deposit ranges from 10 to $12 \mathrm{~m}$.

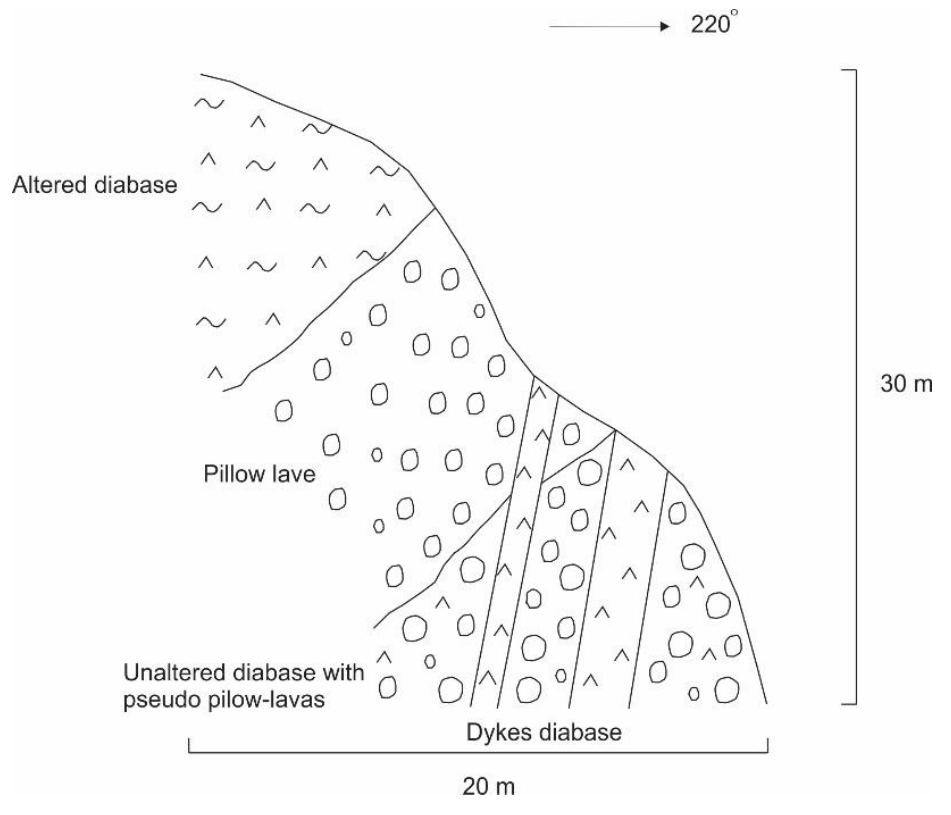

Figure 2 An open profile on the southern part of the Maglajci ophiolitic block

The contact of lava, massive diabase from the described open profile zone and pillow-lavas from the upper levels, is marked with a hyaloclastic material. It is a volcanic glass that is finely splashed in contact with water as it forms and easily alters. The thickness of this clearly visible contact zone is $0.5 \mathrm{~m}$. In the southwestern part of profile base, a dike of keratophyre was mapped, representing the impulse of acidic magma through the basaltic effusion (Fig. 3). The rock is light green with a thickness of $0.6 \mathrm{~m}$. Basaltic effusion are mostly brecciated, so they are penetrated by diabases and keratophyres.

In the upper levels, above the massive basaltic effusion lava, pillow-lavas with a diameter of about $30 \mathrm{~cm}$ are represented (Fig. 5). These are pillowy and ellipsoidal bodies formed by the rapid cooling of lava in an interaction with water. They are densely arranged and connected by a hyaloclastic matrix which is somewhere solider, when it is silenced. "Chillded margins" and intensely altered crust are observed along their edges. Their interior, unlike the edges, is solider with a rarely seen ophitic structure. The thickness of this zone is up to $7 \mathrm{~m}$. The rock has worse physical-mechanical properties, although some zones look solid.

Although this is a small detected area described relative to the surface of the block western part, however, it can be stated that its geological column generally corresponds to the described local one, which was confirmed by drilling and laboratory testing. 


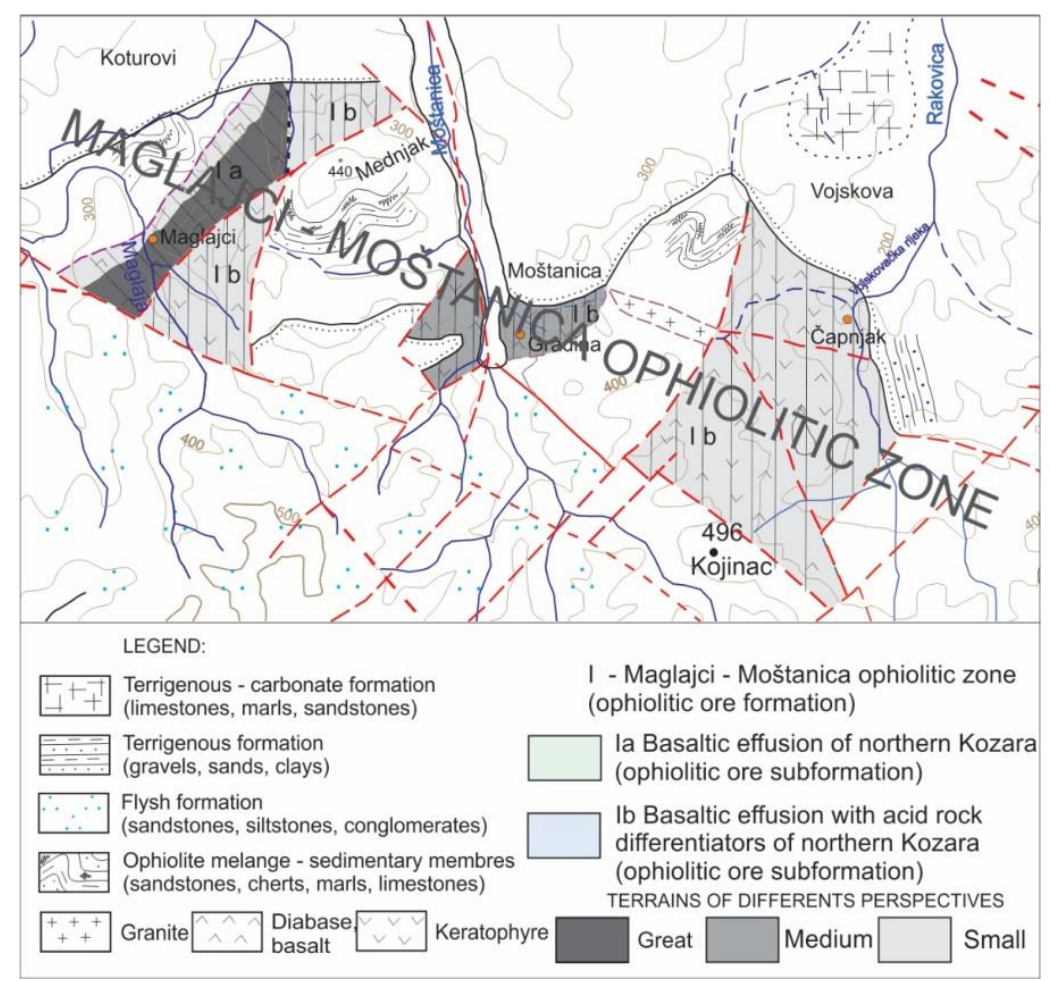

Figure 3 Formation draft of the Maglajci ophiolitic block

The rocks of this part of the block and subformation are ophitic and porphyritic structures and of homogeneous and fluid textures, and hypocrystalline and vitrophyric structures are represented. The geological structure of block and structural characteristics of diabase and basalt are closely related to the genesis, that is, to the sudden outflow and cooling of magma in the marine environment, and with exogenous processes related to the crust of decaying diabase masses. So, this is a surface facies of the basic magma, and in the Maglajci block belongs to the volcanic level. Basaltic effusions are massive or brecciated when penetrated by diabases and keratophyres dykes. Massive outflow is not suitable for the process of embossed. Embossed individual dykes, especially acidic ones, not favorably have effect on the quality of rock mass, and thus the potential of ore formations that contain them.

The described creations of the western part of ophiolitic block of the Maglajci are of a great potentiality. They have relatively low distribution and are excavated on the deposit of Maglajci. The highly promising part is primarily marked by a massive to slightly brecciated basaltic outflow. The rocks are unaltered, solid with the good physical and mechanical characteristics: hardness to pressure $151.94 \mathrm{MPa}$; friction wear "Los Angeles" test (gradation B) 9,2 $\%$; friction wear by the Böhme: 11.01 $\mathrm{cm}^{3} / 50 \mathrm{~cm}^{2}$; water absorption $0.65 \%$ [10]. The crust of decay is variable and ranges from $14 \mathrm{~m}$ to $27 \mathrm{~m}$. The areas of low perspective are classified as the areas of boundary part of the fog block where the diabase is decayed, dilapidated, tectonically processed and hydrothermally altered. 


\subsubsection{Basaltic effusions with acidic rock differentiators of northern Kozara (ophiolitic ore subformation)}

On the southern part of described profile of the block Maglajci, the pillow-lavas are pierced with several diabase polygonal appearance up to $2 \mathrm{~m}$ thick. It is not possible to determine exactly whether the dike broke through the entire mass or breakthrough stopped at the observation site. The dike represents a channel through which magma penetrated and was eventually filled with igneous materials. To the south, acidic differentiators dominate - quartz diabase, spilites, and keratophyres (Figs. 3 and 7).

Apart from the southern part of Maglajaci block, subformation belongs to the Moštanica block in which with diabase and basalt represented keratophyres and granites. These are leucocratic rocks of massive texture with a hypidiomorphic granular structure. The most common occurrence of rocks are slabs of different thickness, less than $1 \mathrm{~m}$ to several meters. Diabases appear as the rocks of ophitic structure, but porphyritic varieties with large plagioclasses are also significantly represented. There are often mandolas with interspaces filled with the secondary material. The ophiolitic block is of medium perspective with the good qualitative characteristics: hardness to

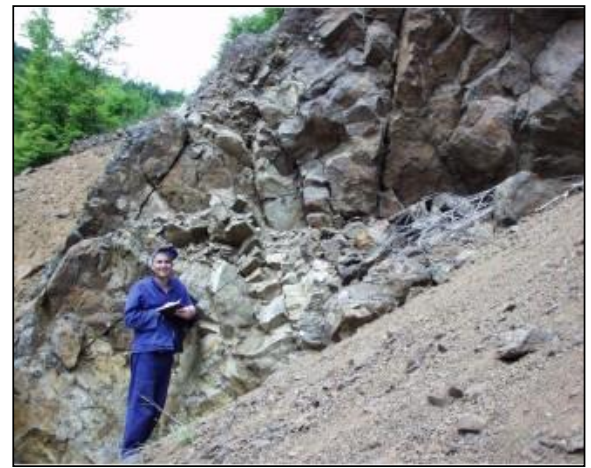

Fig. 4 Brecciated basaltic effusions of the deposit Maglajci have been pierced by the dyke keratophyres pressure 123.68 $\mathrm{MPa}$; friction wear "Los Angeles" test $19.22 \%$; friction wear by the Böhme: $10.76 \mathrm{~cm}^{3} / 50 \mathrm{~cm}^{2}$; water absorption $0.14 \%$.

The Vojskova block with numerous fault zones, crushing zones, etc. also belongs to the subformation. In these zones, the rocks are the most damaged, with the most of expressed alteration processes. Pillow-lavas have been discovered at multiple sites and build mostly peripheral sections of the block. A sample of basalt-andesite from the northeast part of block was tested for chemical composition on major and trace elements by the "whole rock" method, as well as determination the absolute age of zirconia from dolerite by the $\mathrm{U}-\mathrm{Pb}$ method [8]. The obtained age of dolerite on zircons by the $\mathrm{U}$ - $\mathrm{Pb}$ method is $81.4 \mathrm{Ma}$ and fits well with the paleontological and other radiometric determinations from the entire ore formation. The Vojskova block is of a small prospect, due to a large share of keratophyres in the entire rock mass, and then due to a strong tectonic damage that caused wear and tear and decay. This also resulted in a decrease in hardness to pressure, increased friction wear and water absorption, and poor resistance to frost.

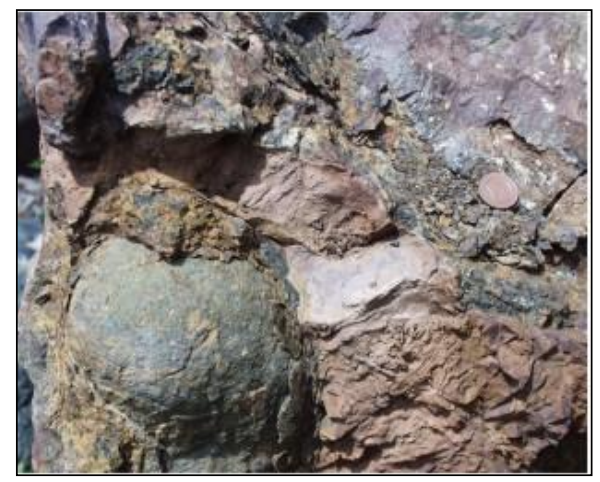

Fig. 5 Pillow-lavas with core and hyaloclastic material of the Maglajci block 


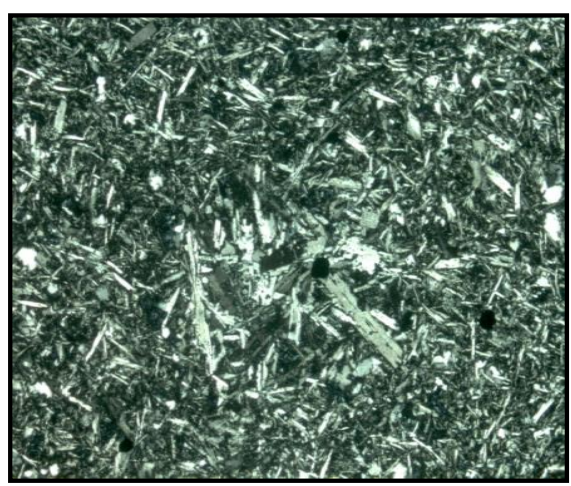

Fig. 6 Crossing plagioclasses in diabase of the Maglajci block

\section{CONCLUSIONS}

- In the northwest of Bosnia and Herzegovina as a part of the regional tectonic unit "Vardar zone western belt", the ore bearing formation ophiolites "Ophiolitic Mélange of the north Kozara" is separated. The formation consists of a sedimentary matrix and blocks of different composition, origin and dimensions. The more prominent magmatic bodies, most often in tectonic contact with the surrounding formations.

- Each of the ophiolitic blocks, by itself or with blocks of similar genetic characteristics, represents a certain ore formation of technical building stone. Specifically developed parts of the ore formations are the ore subformations separated based on their geological and petrological parameters. These parameters, along with the qualitative - quantitative indicators, mark potential surfaces for finding the new deposits.

- The Maglajci - Moštanica ophiolitic zone is built by three ophiolitic blocks and two ore subformations with different geological and petrographic characteristics. The first smaller

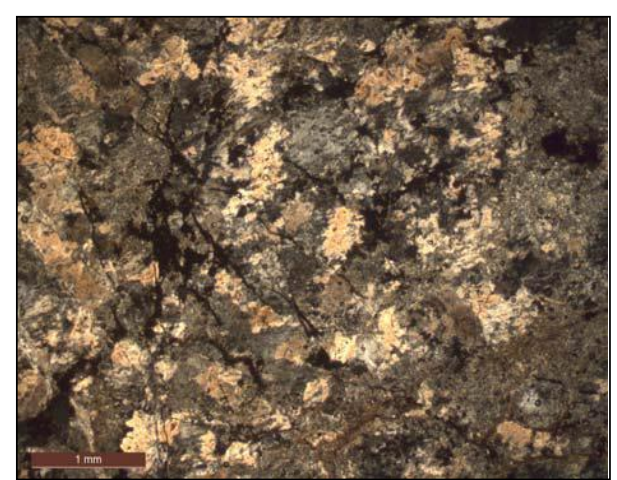

Fig. 7 Micropiolytic strtucture in rhyolite

- "Basaltic effusions of northern Kozara" builds the western parts of the Maglajci block, while the other "'Basaltic effusions with acidic rock differentiators of northern Kozara" belongs to the other magmatic rocks.

- Basaltic effusions of the Maglajci block represent the ore subformation great prospects for the central parts with highly promising fields for expansion the raw materials, whose central parts are highly potential for expanding the raw material base and finding the new deposits. There are rocks with the good physicalmechanical characteristics, and a wide domain of application in construction.

\section{REFERENCES}

[1] Jovanović Č., Magaš N., 1986: Explanatory Book for the Basic Geological Map SFRY 1:100.000, Sheet Kostajnica. Federal Geological Survey, Belgrade.

[2] Grubić A., Milošević A., Cvijić R., (2018): Geology of the Mountains Kozara and Prosara. Monographs, Department of Natural - Mathematical 
and Technical Sciences, Book 37. Academy of Sciences and Arts of the Republic of Srpska. Banja Luka, pp. 241.

[3] Milošević, A., (2013): Ophiolitic Mélange of the North Kozara and Schistes Lustres of Prosara (Geology and Minerogeny). Doctoral Dissertation, Natural Mathematics Faculty in Banja Luka. pp. 131. Banja Luka.

[4] Radoičić, R., (1997): On the Chaotic Formation of Rujevac and Veliki Majdan (Western Serbia). Ibid, Book 47, pp. 53-61. Belgrade.

[5] Pamić, J., Jelaska, V., (1975): Occurrences of the Volcano-Sedimentary Creations of the Upper Cretaceous and Ophiolitic Mélange in the North Bosnia and their Importance in the Geological Composition of the Internal Dinarides. Proceedings of the II Annual Scientific Conference JAZU, pp. 109-117. Zagreb.

[6] Grubić, A., Radoičić, R., Knežević, M., Cvijić, R. (2009): Occurrence of the Upper Cretaceous Pelagic Carbonates within the Ophiolite-Related Pillow Basalts in the Mt. Kozara Area of the Vardar Zone Western Belt, Northern Bosnia. Lithos, Vol. 108, Nos. 1-4, pp. 126-130. Elsevier. Amsterdam.
[7] Grubić, A., Ercegovac, M., Cvijić, R. \& Milošević, A., (2010): The Age of Ophiolite Melange and Turbidites in the North-Bosnian Zone. Bulletin, CXL, Academie Serbe des Sciences et des Arts, Classe des Sciences Mathematiques et Naturelles, Sciences Naturelles, No. 46, pp. 41-56. Belgrade

[8] Ustaszewski K., Schmidt S. M., Lugović B., Schuster R., Schaltegger U., Bernoulli, D., Hottinger, L., Kounov, A., Fuegenschuh, B. \& Schefer, S., (2009): Late Cretaceous Intra-Oceanic Magmatism in the Internal Dinarides (Northern Bosnia and Herzegovina): Implications for the Collision of the Adriatic and Europoean Plate. Lithos, Vol. 108, Nos. 1-4, pp. 106-125. Elsevier. Amsterdam.

[9] Cvetković, V., Šarić, K., Grubić, A., Cvijić, R., Milošević, A., (2014): The Upper Cretaceous Ophiolite of North Kozara - Remnants of an Anomalous Mid-Ocean Ridge Segment of the Neotethys. Geologica Carpathica, Vol. 65, No.2, pp. 117-130. Bratislava.

[10] Milošević, A, (2020): Elaborate on Classification, Categorization and Calculation the Reserves of Technical Building Stone - Diabase on the Maglajci Deposit near Kozarska Dubica. Fund for Professional Documentation of the Faculty of Mining Prijedor. 